\title{
Environmental Modelling of Climate Change Impact on Grapevines: Case Study from the Czech Republic
}

\author{
Ivo Machar ${ }^{1 *}$, Veronika Vlčková2 ${ }^{2}$ Antonín Buček ${ }^{3}$, Kateřina Vrublová1, \\ Jarmila Filippovová ${ }^{1}$, Jan Brus ${ }^{4}$ \\ 'Palacky University Olomouc, Faculty of Science, Department of Development Studies, \\ 17 Listopadu 12, 77146 Olomouc, Czech Republic \\ ${ }^{2}$ Czech Technical University in Prague, Faculty of Transportation Sciences, Department of Applied Informatics, \\ Konviktská 20, 11000 Praha 1, Czech Republic \\ ${ }^{3}$ Mendel University in Brno, Faculty of Forestry and Wood Technology, Department of Forest Botany, \\ Dendrology, and Geobiocoenology, Zemedelska 3, 61300 Brno, Czech Republic \\ ${ }^{4}$ Palacky University Olomouc, Faculty of Science, Department of Geoinformatics, \\ 17 Listopadu 12, 77146 Olomouc, Czech Republic
}

Received: 7 December 2016

Accepted: 8 February 2017

\begin{abstract}
Predicted climate change can significantly affect ecosystem services in agricultural landscapes. Possibilities of predicting climate change effects on growing conditions of crops are therefore sought for practical reasons. The aim of the present study is to contribute to the current discussions about the impact of climate change on agriculture. The case study from the Czech Republic presents methods and results of environmental modelling of the impact of predicted climatic changes on future conditions for growing grapevines. The model is based on the ecological relationship between climate and vegetation zonation of the landscape and thus belongs to the group of process biogeographic models applicable on a regional scale. The results of the presented model show significant enlargement of areas climatically suitable for growing grapes within the studied area. The results of the model relevant to the Czech Republic are in line with the previous assumptions of trends in future impacts of climate change on viticulture in Europe. However, the data resulting from the presented model, which relate to the time horizon beyond 2050, should be regarded as indicative and fraught with a high degree of uncertainty linked with the uncertainty of the input climatological prediction for this time period.
\end{abstract}

Keywords: agricultural crops, biogeographical model, climate change, vegetation zones

*e-mail: ivo.machar@upol.cz 


\section{Introduction}

Grapevine (Vitis vinifera L.) is one of the oldest crops in the world [1] and its cultivation is reflected in the regional identity of people from different geographical regions [2]. Vineyards have formed the structure of cultural landscapes of climatically suitable regions for centuries [3]. The growth and production of grapevines grown in vineyards is significantly affected by a number of environmental factors [4]. Individual cultivars respond to environmental factors differently in terms of the resulting wine quality [5], which is reflected in concrete and regional-specific characteristics of wines [6]. The specific effects of environmental factors on the quality of wine are called "terroir" [7] and known in many wine regions, e.g., France [8]. As regards climatic conditions, temperature is a crucial factor for the thermophilic grapevine [9]. This fact is important in the context of current discussions about global warming [10], which is likely to have an increasing effect on the possibilities of grapevine cultivation [11] as well as on the economy of vineyard production [12].

In Europe there is a very dense network of longterm measuring weather stations with a variety of complementary distance measurement systems and, therefore, the analyses of temperature trends are much more accurate in Europe than anywhere else in the world. The temperature of the European continent increased on average by $1.2^{\circ} \mathrm{C}$ during the 20th century, the average number of summer days doubled, and the average number of tropical days tripled [13]. These changes obviously have important environmental implications for European agriculture and for the formulation of the priorities of agricultural policy in Europe [14].

Also, trends in long-term meteorological measurements taken in the Czech Republic show a significant increase in average air temperature and, additionally, a marked increase in the incidence of weather extremes - the numbers of tropical and summer days and nights increase and the numbers of frost days and ice days decrease [15]. Analysis of the stability and diversity of agricultural production in the Czech Republic (CR) in the last 75 years shows that the changes of climatic factors have had a positive effect on the production of certain agricultural crops (higher production) [16]. Linear trends in regional temperature and precipitation amounts in the Czech Republic (i.e., the modified values derived from data measured by station network, which take into account the position of individual meteorological stations) confirm the increase in average temperatures and decrease in the total precipitation amounts in all seasons of the year except winter, and at the same time dramatic increases in extreme weather events [17]. Such development of climate may be associated with adverse environmental consequences for agricultural production [18]. Also, the results of a broad-based questionnaire focused on the views of agroclimatic experts and agronomists from 26 countries of Europe showed a surprisingly high proportion of negative expectations concerning the impacts of climate change on agricultural crops and production throughout Europe [19].
Vegetation zones are a suitable environmental frame for the evaluation of possible climate change impacts on the growing conditions of agricultural crops in the Czech Republic [20], because the distribution of vegetation zones in the Czech landscape reflects the character of the orographically conditioned differences in climatic conditions and their gradients. In the Czech Republic, vegetation zones were originally defined using bioindication as a basic environmental framework for the creation of a national ecological network [21]. Based on the vegetation zonation, a model predicting shifts in climate conditions of vegetation zones according to climate change scenarios was developed in the Czech Republic. The model allows us to predict the impact of climate change on the environmental conditions of various agricultural crops on a regional scale [22].

The aim of this paper is to follow the published analysis of the current state of viticulture in the Czech Republic [23] and predict the future development in the context of climate change, and thus contribute to the current discussions about climate change impacts on the biotic components of the landscape.

\section{Methods and Materials}

The biogeographical model of the shift in climate conditions of vegetation zones due to predicted climate change, which was used in this study, can be classified into the group of process biogeographic models that are used to predict the equilibrium vegetation responses to potential climate change on a regional or global scale [24]. These models identify ecological restrictions in relation to the distribution of plant formations (vegetation zones) under different equilibrium climatic conditions [25]. The model applied within this study is based on the ecological relationship between the current climate and the distribution of vegetation zones in the landscape [26]. It is based on the assumption that the general ecological relationship between vegetation zones and climatic conditions also will be maintained in the future [27]. The projected climate change may, therefore, be manifested by a shift in the climate conditions of vegetation zones on a regional scale [28].

The prediction climatic database of the Czech Hydrometeorological Institute (CHMI) was used as the source of climatological data for the model; data on annual precipitation, annual average relative humidity, and annual average daily sums of global radiation, annual average air temperature, and annual average wind speed were used. This database links climatic data to a set of 131 points regularly spaced throughout the Czech Republic in the form of a regular trapezoidal network, and contains a validated database of climatic elements calculated by the ALADIN-CLIMATE.CZ model for the period from 2010 to 2100 according to the SRES A1B scenario [29].

A biogeography register [30] was used as the source of geobiocoenological data for the model. It contains geobiocoenological classification of the landscape in the 


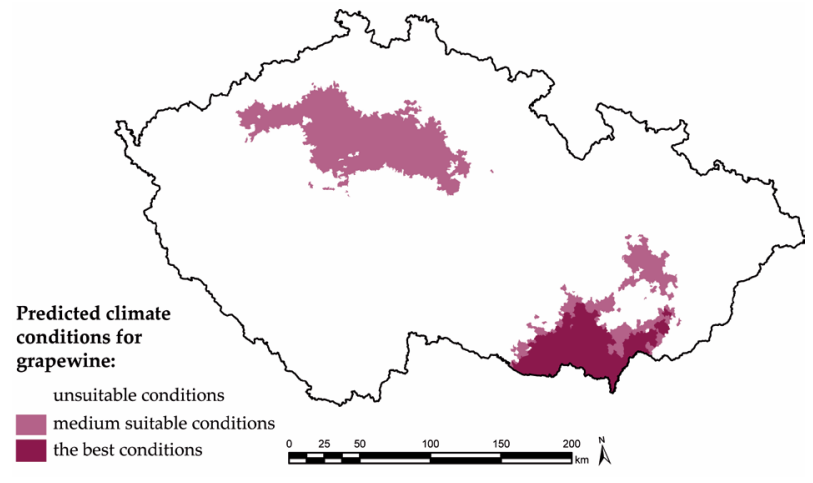

Fig. 1. Current areas suitable for growing grapevine in the Czech Republic according to vegetation zonation.

Czech Republic (vegetation zones, trophic, and hydric series) projected on the selected type of administrative spatial units of the Czech Republic's cadastral territories. The biogeography register contains descriptions of geobiocoenological properties of approximately 13,000 polygons (cadastres), fully covering the area of the Czech Republic. This database describes quite well the heterogeneity of natural conditions in the Czech Republic owing to the link to cadastral territories because the original cadastres were delimited in the 19th century according to natural boundaries such as streams, forest borders, and marked geomorphological features in the landscape [31].

The computer model of the shift in climate conditions of vegetation zones due to climate change is designed as a set of special programs (FORTRAN programming language) and Arc/Info GIS applications [32]. The definition points of the Biogeography register were assigned climatic characteristics using an analytic-geometric method designing a more detailed network of points in the area (250 $\mathrm{m} \mathrm{step),} \mathrm{to} \mathrm{which} \mathrm{the} \mathrm{values} \mathrm{of} \mathrm{climatic} \mathrm{variables}$ were recalculated by the gradient method using the values relevant to the four nearest neighbouring points of the original CHMI climatic database. Based on the analysis of the current environmental conditions in wine regions of the Czech Republic, the current conditions for growing grapes were algorithmized into vegetation zones and geobiocoenological characteristics of hydric and trophic series. Projected climatic characteristics of the definition points, the corresponding vegetation zones, and the characteristics of natural climatic conditions were determined using the method of space-time analogies, for which Lang's rain factor, which combines the average annual rainfall and average annual temperature into a single value, was employed as a relationship indicator [33].

\section{Results}

Fig. 1 shows the result of the algorithmization of the current climate conditions for growing grapevine into vegetation zones and geobiocoenological characteristics of hydric and trophic series. It is clear that the current area with optimal climate conditions for growing grapes in the first and second vegetation zone copies the area of the traditional wine-growing regions in the Czech Republic [34]. Areas with ecological conditions unsuitable for growing grapes include vegetation zones, and trophic and hydric series (e.g., waterlogged alluvial hydric series) that do not comply with the growth requirements of grapevine.

The graph in Fig. 2 shows the predicted trend in Lang's rain factor values in the regions climatically suitable for growing grapes in the Czech Republic in 10-year forecast

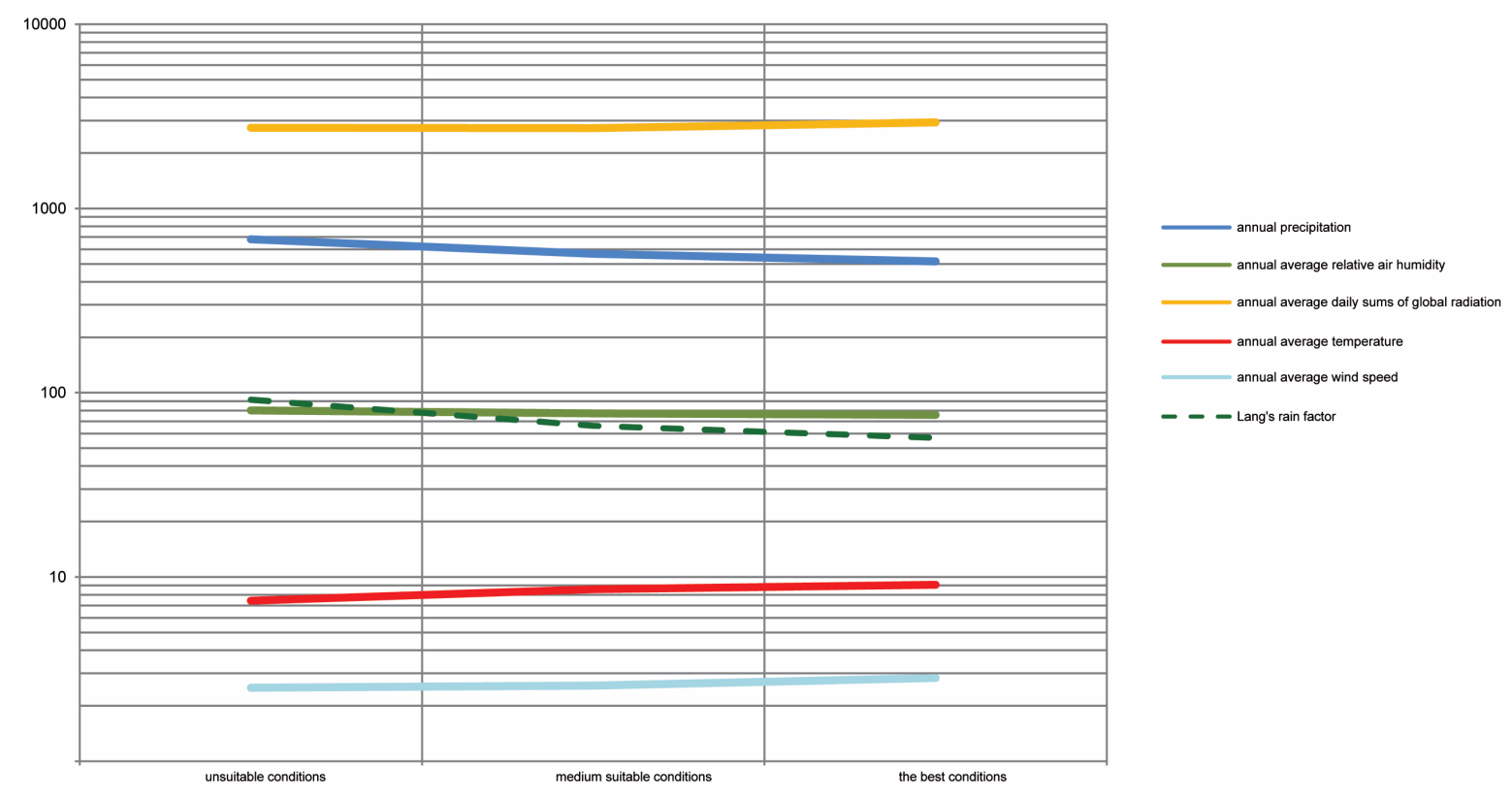

Fig. 2. Predicted trend in Lang's rain factor values in areas climatically suitable for growing grapevine in the Czech Republic in ten-year time horizons. 


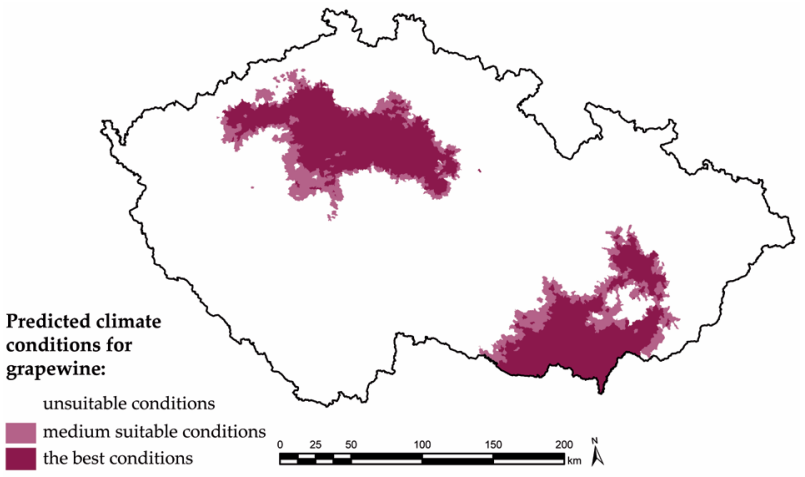

Fig. 3. Predicted delimitation of areas suitable for growing grapevine in the Czech Republic in 2050 time horizon.

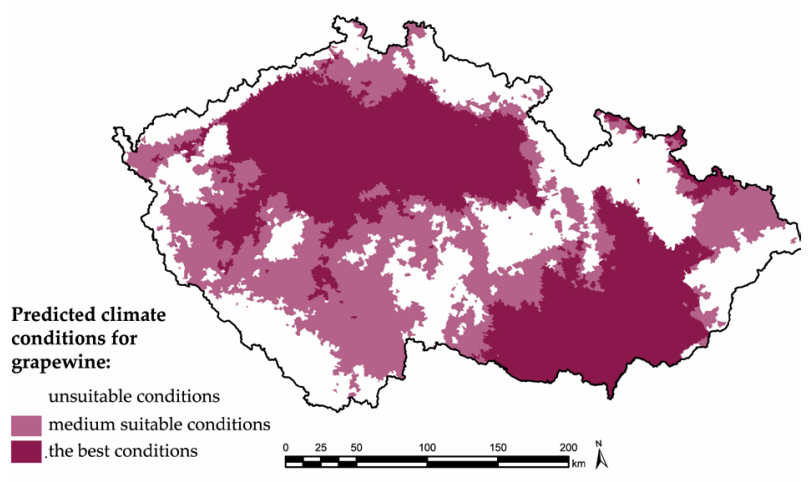

Fig. 4. Predicted delimitation of areas suitable for growing grapevine in the Czech Republic in 2070 time horizon.

horizons. Graphical data in the prediction period up to 2090 refer to the initial trends of measured values of the average annual precipitation and average annual temperatures for the period 1961-2009.

The map in Fig. 3 illustrates the predicted delimitation of areas with suitable climate conditions for growing grapes for the forecast time horizon of 2050, and Fig. 4 for the forecast time horizon of 2070. Both figures show a clear trend toward the expansion of areas with suitable climate for growing grapes in the Czech Republic. The total area of regions with optimal climate conditions for growing grapes should increase by $10 \%$ in 2050 compared to the present situation. This finding suggests that the predicted changes in climate may have positive effects on agricultural production in the studied area as regards thermophilic crops such as grapes (enlargement of the total productive area). In 2070 the increase in the total area of regions with optimal climate conditions for growing grapes should reach $38 \%$ of the area of the Czech Republic, but the prediction for this time horizon provides only indicative data (in relation to the degree of uncertainty in the underlying climate prediction data for this time period).

The graph in Fig. 5 shows the detailed results of the model predicting the temporal and spatial trends in the development of the areas climatically suitable for growing

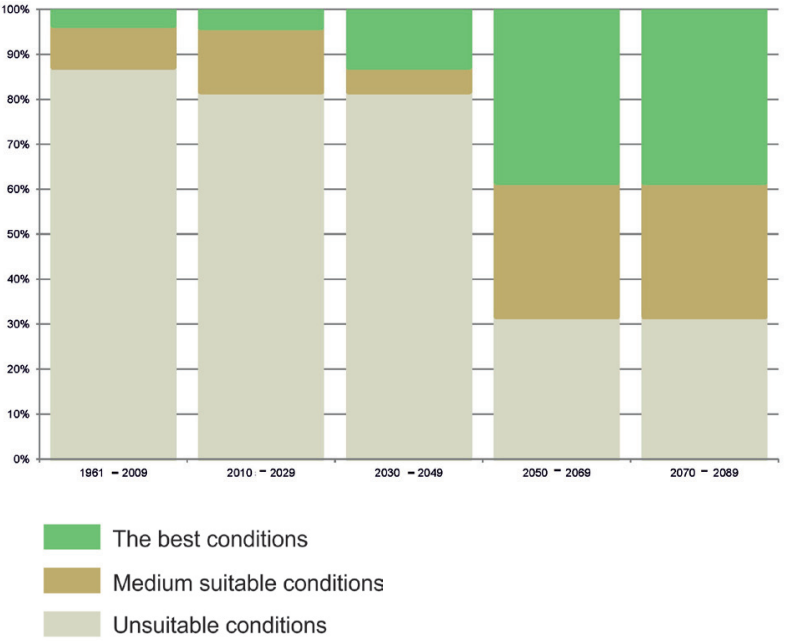

Fig. 5. Prediction of temporal and spatial trends in the development of areas suitable for growing grapevine in the Czech Republic in relation to the trend in the shifts in vegetation zonation in ten-year time horizons until 2091.

grapes in the Czech Republic. The graph generally corresponds with the cartographic expression of the development trends in Figs 3 and 4 but presents the model prediction of the impact of climate change on the growing conditions of grapevines in detail - in 10-year time steps. The graph thus shows the possibilities of the employed model that reaches the time horizon of 2089 , which is the limit for the prediction capability of the model in relation to the input climate prediction data. However, the figures in this graph, which relate to the time horizon beyond 2050, should be regarded as indicative data fraught with a high degree of uncertainty of the climatological prediction.

\section{Discussion and Conclusions}

The grapevine grown in vineyards probably originated from a wild grape subspecies Vitis vinifera sylvestris $\mathrm{C}$. C. Gmelin [35], which can still be rarely found in the warmest lowland regions in the Czech Republic [36]. Viticulture in the Czech Republic, as well as the entire agricultural sector and the entire agricultural landscape, underwent fairly extensive organizational and economic changes in the 1990s due to political events [37]. Another major turning point in the development of viticulture is connected with the accession of the Czech Republic to the European Union. The issue of changes in viticulture in the Czech Republic has been a subject of much research [38].

The current trend in viticulture in major wine production areas of the world is directed toward quality production instead of quantity [39]. The importance of research focused on environmental factors affecting the cultivation of grapevine increases in the context of increasing consumer interest in high-quality wines [40]. The cultivation of grapevine in the near future will be affected by climate change and, therefore, this issue has attracted the increasing attention of researchers [41]. 
Specialized experimental studies or mathematical modelling are often used to evaluate the potential impacts of ongoing and expected climate change on agricultural production. However, it must always be taken into account the fact that mathematical models do not represent predictions of future development. Models contribute to the predictions but their results must be carefully interpreted on the basis of knowledge of biology or ecology of organisms that are modelled [42].

The vast majority of the hitherto proposed models are correlation models that are based on the interdependence (a function or algorithm) between certain bioclimatic variables of the environment (usually average temperature and average rainfall) and the current range of a species or the characteristics of an ecological niche of a species [43]. When you predict future changes in climatic conditions on the basis of climate scenarios, you can assign relevant biological species or communities to the changed variables. This procedure is known as bioclimatic envelope modelling [44]. For example, the model predicting the effects of climate change on the growing conditions of sugar beet in the Slovak Republic was based on the evaluation of the current production potential of agricultural soils expressed by estimated pedologicecological units that were assigned environmental growth requirements and production parameters of sugar beets [45].

The biogeographic regional model used in this article uses the dependence of vegetation on the long-term effects of altitude and climate exposure, which is determined by the average and extreme air temperatures and the amount and distribution of precipitation (including horizontal precipitation). The current vegetation zones in the Czech Republic stabilized in the older subatlantic about 800-500 $\mathrm{BC}$, and the shifts of vegetation zones in the landscape faithfully reflect the progress of climate change. The delimitation of the current vegetation zones in the Czech Republic was elaborated in great detail in the context of the creation of bio-geographical basis for the national ecological network of the landscape [46] and, therefore, the current vegetation zonation is a suitable basic initial framework for the modelling of the effects of climate on production and growing conditions of the vegetation in the Czech Republic.

The simulation of redistribution of climate conditions for vegetation zones within biogeographic models is essentially a static (equilibrium) perspective of the analysed problem as these models represent modelling of a certain level of carbon dioxide concentration at some time in the future (while ignoring the more realistic accumulation of carbon dioxide over time on a local scale). Static/equilibrium biogeographic models provide useful "images" of terrestrial ecosystems in equilibrium with certain climatic conditions [47]. The application of these models, however, has its limitations as they do not simulate internal factors of vegetation dynamics (competition, mortality, physiological factors, etc.). Dynamic global vegetation models [48] have been newly developed to overcome these limitations. These models integrate vegetation dynamics and ecosystem functions, but are not yet applicable in a regional scale [49].

The development of climate significantly affects the geographical distribution of organisms in ecosystems and human activities such as agriculture [50]. Possibilities of predicting the effects of climate change on growing conditions of agricultural crops are therefore sought for practical reasons. The study from the Czech Republic dealing with the impact of predicted climate change on the possibilities of grapevine cultivation as presented in this article aims to contribute to the current discussions about the effects of climate change on agriculture [51]. The results of the presented model of the shift in vegetation zones due to predicted climate change show significant enlargement of areas climatically suitable for growing grapes within the studied area. The results of the model relevant to the Czech Republic are in line with the previous assumptions of trends in future impacts of climate change on viticulture [52]. The data resulting from the model, which relate to the time horizon beyond 2050, should be regarded as indicative and fraught with a high degree of uncertainty linked with the uncertainty of the input climatological prediction for this time period.

Despite the attention which has been recently given to the research into the effects of climate change on various taxonomic groups of organisms, it is clear that our ability to predict changes in the abundance and distribution of both cultural and wild plant species due to climate change remains limited in the context of statistical and stochastic uncertainties in environmental data.

\section{Acknowledgements}

The authors thank anonymous reviewers for comments and recommendations to the manuscript. The authors also thank staff members J. Pretel and R. Tolasz of the Czech Hydrometeorological Institute for providing climatological data from the project "Refining Estimates of the Impacts of Climate Change on Water Management, Agriculture and Forestry and Proposals for Adaptation Measures" (MŽP VaV SP/1a6/108/07). The work on this article was supported by a joint grant of Palacky University in Olomouc and Mendel University in Brno: "Platform for cooperation in the field of shaping the landscape (ABIONET)" (No. CZ.1.07/2.4.00/31.0032).

\section{References}

1. BALTER M. Seeking Agriculture's Ancient Roots. Nature 316, 1830, 2007.

2. NEWMAN J.L. Vines, wines, and regional identity in the Finger Lakes Region. Geographical Review 76 (3), 301, 1986.

3. SUPUKA J., VEREŠOVÁ M., ŠINKA K. Development of vineyards landscape structure with regard to historical and cultural values. Ekológia (Bratislava) 30 (2), 229, 2011. 
4. FERRANDINO A., LOVISOLO C. Abiotic stress effects on grapevine: Focus on abscisic acid-mediated consequences on secondary metabolism and berry quality. Environmental and Experimental Botany 103, 138, 2014.

5. PEDRI U., PERTOLL G. Influence of different locations on grape and wine quality with the grapevine variety 'Pinot blanc'. Mitteilungen Klosterneuburg 63 (4), 173, 2013.

6. FLAKW.,WUKETICHA.,KRIZANR., TIEFENBRUNNER W., WALLNER E. An approach to the sensory determination of wine terroir. Mitteilungen Klosterneuburg 62 (1), 37, 2012.

7. DOUGHERTY P.H. The Geography of Wine: Regions, Terroir and Techniques. Springer, 2012.

8. GADE D.W. Tradition, Territory and Terroir in French viniculture. Annals of the Association of American Geographers 94 (4), 848, 2004.

9. FENNELL A. Genomics and Functional Genomics of Winter Low Temperature Tolerance in Temperate Fruit Crops. Critical Reviews in Plant Sciences 33 (2-3), 125, 2014.

10. FLANNERY T. The Weather Makers: The History and future Impact of Climate Change. Melbourne: T Publishing Company, 2005.

11. SCHILDBERGER B. Viticulture during Climate Change: Possibilities for Adjustment and Mitigation; the Example of the Model Region of Traisental. Mitteilungen Klosterneuburg special issue 2011, 180, 2011.

12. ASHENFELTER O., STORCHMANN K. Using Hedonic Models of Solar Radiation and Wheather to Assess the economic Effect of Climate Change: The Case of Mosel Valley Vineyards. Review of Economics and Statistics 92 (2), 333, 2010.

13. KEBEDE A.S., DUNFORD R., MOKRECH M., AUDSLEY E., HARRISON P.A., HOLMAN I.P., NICHOLLS R.J., RICKEBUSCH S., ROUNSEVELL M.D.A., SABATE S., SALLABA F., SANCHEZ A., SAVIN C., TRNKA M., WIMMER F. Direct and indirect impacts of climate and socio-economic change in Europe: a sensitivity analysis for key land- and water-based sectors. Clim. Change 128, 261, 2015.

14. OLESEN J.E., BINDI M. Consequences of climate change for european agricultural productivity, land use and policy. European Journal of Agronomy 16, 239, 2002.

15. MACKU J. Climatic characteristics of forest vegetation zones of the Czech Republic. Journal of Landscape Ecology 7, 39, 2014

16. TRNKA M., BRAZDIL R., DUBROVSKY M., SEMERADOVA D., STEPANEK P., DOBROVOLNY P., MOZNY M., EITZINGER J., MALEK J., FORMAYER H., BALEK J., ZALUD Z. A 200-year climate record in Central Europe: implications for agriculture. Agronomy for Sustainable Environment 31, 631, 2011.

17. PRETEL J. Současný vývoj klimatu a jeho výhled. (Current development of climate and predictions.) Ochrana prírody 46, 2, 2009.

18. TRNKA M., DUBROVSKÝ M., ŽALUD Z. Climate change impacts and adaptation strategies in Spring Barley production in the Czech Republic. Climatic Change 64, 227, 2004.

19. OLESEN J.E., TRNKA M., KERSEBAUM K.C., SKLEJVAG A.O., SEGUIN B., PELTONEN-SAINIO P., ROSSI F., KOZYRA J., MICALE F. Impacts and adaptation of European crop production systems to climate change. European Journal of Agronomy, 34, 96, 2011.

20. VAHALÍK P., MIKITA T. Possibilities of forest altitudinal vegetation zones modelling by geoinformatic analysis. Journal of Landscape Ecology (Brno) 4 (2), 49, 2011.

21. BUČEK A., MADĚRA P., ÚRADNÍČEK L. Czech approach to implementation of ecological network. Journal of Landscape Ecology (Brno) 5 (1), 14, 2012.

22. KOPECKÁ V., MACHAR I., BUČEK A., KOPECKÝ A. The Impact of Climate Changes on Sugar Beet Growing Conditions in the Czech Republic. Listy cukrovarnické a řepařské 129 (11), 326, 2013.

23. SVOBODOVÁ I., VĚŽNÍK A., KRÁL M. Viticulture in the Czech Republic: some spatio-temporal trends. Moravian Geographical Reports 22 (1), 2, 2014.

24. PETERSON A.T., TIAN H., MARTÍNEZ-MEYER H., SOBERÓN J., SÁNCHES-CORDERO V., HUNTLEY B. Modeling Distributional Shifts of Individual Species and Biomes. In: Lovejoy T.E and Hannah L. (eds.): Climate Change and Biodiversity. New Haven and London: Yale Univ. Press, 211, 2005.

25. GIORGI F., HEWITSON B., CHRISTENSEN J., HULME M., VON STORCH H., WHETTON P., JONES R., MERNS I., FU C. REGIONAL CLIMATE INFORMATION EVALUATION AND PROJECTION. IN: HOUGHTON J.T., DING Y., GRIGGS D.J., NOGUER M., VAN DER LINDEN P., DAI X., MASKELL K., JOHNSON C.I. Climate Change 2001 - The Scientific Basis. New York: Cambridge Univ. Press, 583, 2002.

26. KIRILENKO A.P., SOLOMON A.M. Modeling dynamic vegetation response to rapid climate change using bioclimatic classification. Climatic Change 38, 15, 1998.

27. YEE T.W., MITCHELL N.D. Generalized additive models in plant ecology. Journal of Vegetation Sciences 2, 587, 1991.

28. WOODWARD F.I., LOMAS M.R., BETTS R.A. Vegetationclimate feedback in a greenhouse world. Philosophical Transactions of the Royal Society of London 353, 29, 1998.

29. PRETEL J. Refinement of climate change impacts to water, forest and agricultural management and adaptation measures - grant no. SP/1a6/108/07. Praha: ČHMÚ, 2011 [In Czech].

30. MACHAR I. Applying of the Biogeography Register to Predicting the Consequences of Global Climate Changes on the Landscape in the Czech Republic. In: Advances in Environment, Ecosystems and Sustainable Tourism. Proceedings of the $11^{\text {th }}$ Int. Conference on Environment, Ecosystems and Development. Brasov, Romania: 15, 2013.

31. SKALOŠ J., ENGSTOVÁ B. Methodology for mapping non-forest wood elements using historic cadastral maps and aerial photographs as a basis for managemenet. Journal of Environmental Management 91, 831, 2010.

32. VLČKOVÁ V. Systems of climate change impacts modelling using GIS tools. Acta Informatica Pragensia 3 (1), 70-88, 2014.

33. BUČEK A., VLČKOVÁ V. Scenario of vegetation zones change in the Czech Republic. Ochrana př́rody 64, 8, 2012.

34. BLAHA J., MRKOS J. Grapevine and climate conditions in the frame of Moravia region. Vinařský obzor 40 (7-9), 1, 1940.

35. HÁJKOVÁ L., VOŽENÍLEK V., TOLASZ R., KOHUT M., MOŽNÝ M., NEKOVÁŘ J., NOVÁK M., REITSCHLÄGER J.D., RICHTEROVÁ D., STŘIZŽ M., VÁVRA A., VONDRÁKOVÁ A. Atlas of the Fenological Conditions in Czechia. Olomouc: Palacky University, 311, 2012. 
36. MADĚRA P., MARTÍNKOVÁ M. Assessment of the occurence of Vitis vinifera subsp. sylvestris in the Czech Republic. Ekológia (Bratislava), 48 (11), 482, 2002.

37. LIPSKÝ Z. The changing face of the Czech rural landscape. Landscape and Urban Planning 31, 39, 1995.

38. CHLÁDKOVÁ H., TOMŠÍK P., GURSKÁ S. The development of main factors of the wine demand. Agricultural Economics 55 (7), 321, 2009.

39. MARKS D. Competitiveness and the Market for Central and Eastern european Wines: a Cultural Good in the Global Wine Market. Journal of Wine Research 22 (3), 245, 2011.

40. VAUDOUR E. The Quality of Grapes and Wine in Relation to Geography: Notions of Terroir at Various Scales. Journal of Wine Reserach 13 (2), 117, 2002.

41. PIERI P., LEBON E., BRISSON N. Climate Change Impact on French Vineyards as Predicted by Models. Acta Horticulturae 931, 29, 2012.

42. WALTHER G.R., POST E., CONVEY P., MENZEL A., PARMESAN C., BEEBEE T.J.C., FROMENTIN J.M., HOEGH-GULDBERG O., FAIRLEIN F. Ecological responses to recent climate change. Nature 416, 389, 2002.

43. PETERSON A.T., SOBERON T.J., SANCHEZ-CORDERO V. Conservatism of ecological niches in evolutionary time. Science 285, 1265, 1999.

44. BOTKIN D.B., SAXE H., ARAUJO M.B., BETTS R. BRADSHAW R.H.W., CEDHAGEN T., CHESSON P., DAWSON T.P., ETTERSON J.R., FAITH D.P., FERRIER S. GUISAN A. HANSEN A.S., HILBERT D.W. LOEHLE C. MARGULES C. NEW M., SOBEL M.J., STOCKWELL D.R.B. Forecasting the effects of global warming on biodiversity. BioScience 57, 227, 2007.

45. VILČEK J. Dopad klimatických zmien na možnosti pestovania cukrovej repy na Slovensku. Listy Cukrovarnické a Řepařské 124 (3), 78, 2008.
46. KOVÁŘ P., MADĚRA P. Adapting landscapes and response to global ecological change. Journal of Landscape Ecology (Brno) 3 (2), 5, 2010.

47. NEILSON R.P., PRENTICE I.C., SMITH B. Simulated changes in vegetation distribution under global warning. In: Watson R.T., Zinyowera M.C., Moss R.H., Dokken D.J. (eds), The Regional Impacts of Climate Change - An Assessment of Vulnerability. Cambridge: Cambridge Univ. Press, 439, 1998.

48. PRENTICE I.C., WEBB N.R. Developing a global vegetation dynamics model: Results of an IIASA. Laxenburg: Institute for Applied Systems Analysis, 1989.

49. BACHELET D.R., NEILSON R.P., LENIHAN J.M., DRAPEK R.J. Climate change effects on vegetation distribution and carbon budget in the U.S. Ecosystems 4, 164, 2001.

50. HARRISON P. A., BUTTERFIELD R. E., DOWNING T, E. Climate change and agriculture in Europe: assessment of impacts and adaptations. Oxford: Environmental Change Unit, University of Oxford, 411, 1995.

51. TRNKA M., OLESEN J.E., KERSEBAUM K.C., SKJELVAGA.O., EITZINGER J., SEGUIN B., PELTONENSAINIO P., RÖTTER R., IGLESIAS A., ORLANDINI S., DUBROVSKÝ M., HLAVINKA P., BALEK J., ECKERSTEN H., CLOPPET E., CALANCA P., GOBIN A., VUČETIC V., NEJEDLIK P., KUMAR S., LALIC B., MESTRE A., ROSSI F., KOZYRA J., ALEXANDROV V., SEMERÁDOVÁ D., ŽALUD Z. Agroclimatic conditions in Europe under climate change. Global Change Biology 17, 2298, 2011.

52. SADRAS V.O., BUBNER R., MORAN M.A. A large-scale, open-top system to increase temperature in realistic vineyard conditions. Agricultural and Forest Meteorology 154, 187, 2012. 